Research supervisor: A.P.Lisnychenko

Candidate of Pedagogical Sciences,

Senior Lecturer

Vinnytsia Mykhailo Kotsjubinsky State University

Language tutor: N.Y.Prokopovych

\title{
COMMUNICATIVE APPROACH IN FOREIGN LANGUAGE TEACHING
}

The process of communication and its different aspects are the basic issues of Foreign Languages Methodology which have been studied and analyzed by scientists for many years.

As K. Johnson and K. Morrow point out, the communicative approach differs from more traditional approaches in which the attention is focused on the learning of structural competence in foreign language teaching [1, p.10].

K. Johnson, a British Methodologist, states that there are two communicative approaches in foreign language teaching:

1) the perfect organization of the curriculum;

2) methodology.

Indeed, the first approach determines what to study following the communicative principle and the other one shows how and by means of which methods to make language learning more effective.

Communicative approach is oriented on language learning through communication. The characteristic features of communicative approach in language teaching are the following:

1) the communicative orientation of all types of learning;

2) "learner-centered approach";

3) "the whole-person approach";

4) educational materials are submitted according to the functional principal;

5) the main types of work are: 
a) pair work (dialogue);

b) group work (polylog);

6) nontraditional relation to mistakes $[1, \mathrm{p} .70]$.

However, the communicative approach of foreign language teaching is often an object of criticism because it encourages pupils to make mistakes. The reason of such mistakes is ambiguous. Firstly, this is what the student is taught by a teacher who believes that accidental mistakes of grammar or pronunciation do not matter.

Secondly, the pupil can be involved in a communicative situation, to which he wasn't prepared and, trying to realize it, makes mistakes. This fact shows the relation and the reaction to these mistakes [2, p. 82].

In general, it is believed that the use of communicative tasks in the process of foreign language teaching is complex. Foreign language teaching should be directed at developing learners' ability to use the language correctly in real communicative situations.

\section{References}

1. Johnson K., Morrow K. Communication in the Classroom. - Longman Groop, 1992. - 140p.

2. Widdowson G. Teaching language as Communication. - Oxford University Press, 1990. - 168p. 